colors and manner of flight, also imitates them in resting lightly on the flowers and extracts pollinia less frequently than any wasp I have seen.

Explanation of Plate XII.--Fig. 1, Gynostegium of Asclepias verticilata L., with one hood removed. Fig. 2, Same, of Asclepias purpurascens L. Fig. 3, Gynostegium of Acerates longifolia Ell. Fig. 4, Sketch of Bombus scutellaris Cress., with polliniāo of Acerates longifolia. Fig. 5, Sketch of face of Cerceris bicornuta Guér., with pollinia of Acerates longifolia. Fig. 6, Pollinia of Acerates viridiflora Ell.; one in stigmatic chamber with tubes emitted. Fig. 7, Corpusculum of same, "spiked" and displaced by caudicle of inserted pollinium.

\title{
The "Curl" of Peach Leaves: a study of the abnormal structure induced by Exoascus deformans. ${ }^{1}$
}

ETTA L. KNOWLES.

(WITH PLATE XIII.)

The fungus which causes the disease of peach leaves, known as "the curl," appears very soon after the leaf unfolds. The following observations were made from alcoholic material gathered May 30 , and June 8, 1887. The fungus continued to make its appearance on growing leaves up to the time of concluding this work, at the end of June, but was less abundant at that time than early in the month.

A study of the structure of the normal leaf was first made to serve as a basis of comparison with that of the diseased leaf. The drawings were all made with the camera. Fig. I represents a cross section of a healthy peach leaf, $a$ being the upper and $b$ the lower surface. The epidermis consists of a single layer of cells, the outer walls of which are covered with a very thin, delicate cuticle. The epidermal cells of the two surfaces differ considerably in shape and size, as shown in the figure. Next to the epidermal layer of the lower surface are ordinary parenchymatous cells, thin-walled, irregular in shape and arrangement, and with large intercellular spaces. Beneath the epidermis of the upper surface are from two to three layers of palisade cells, likewise thin-walled, but with smaller intercellular spaces. The cells are filled with granular protoplasm in which are round masses of chlorophyll. On the under surface are numerous stomata. Both

\footnotetext{
${ }^{1}$ Contributions from the Botanical Laboratory of the University of Michigan, 1887
} 

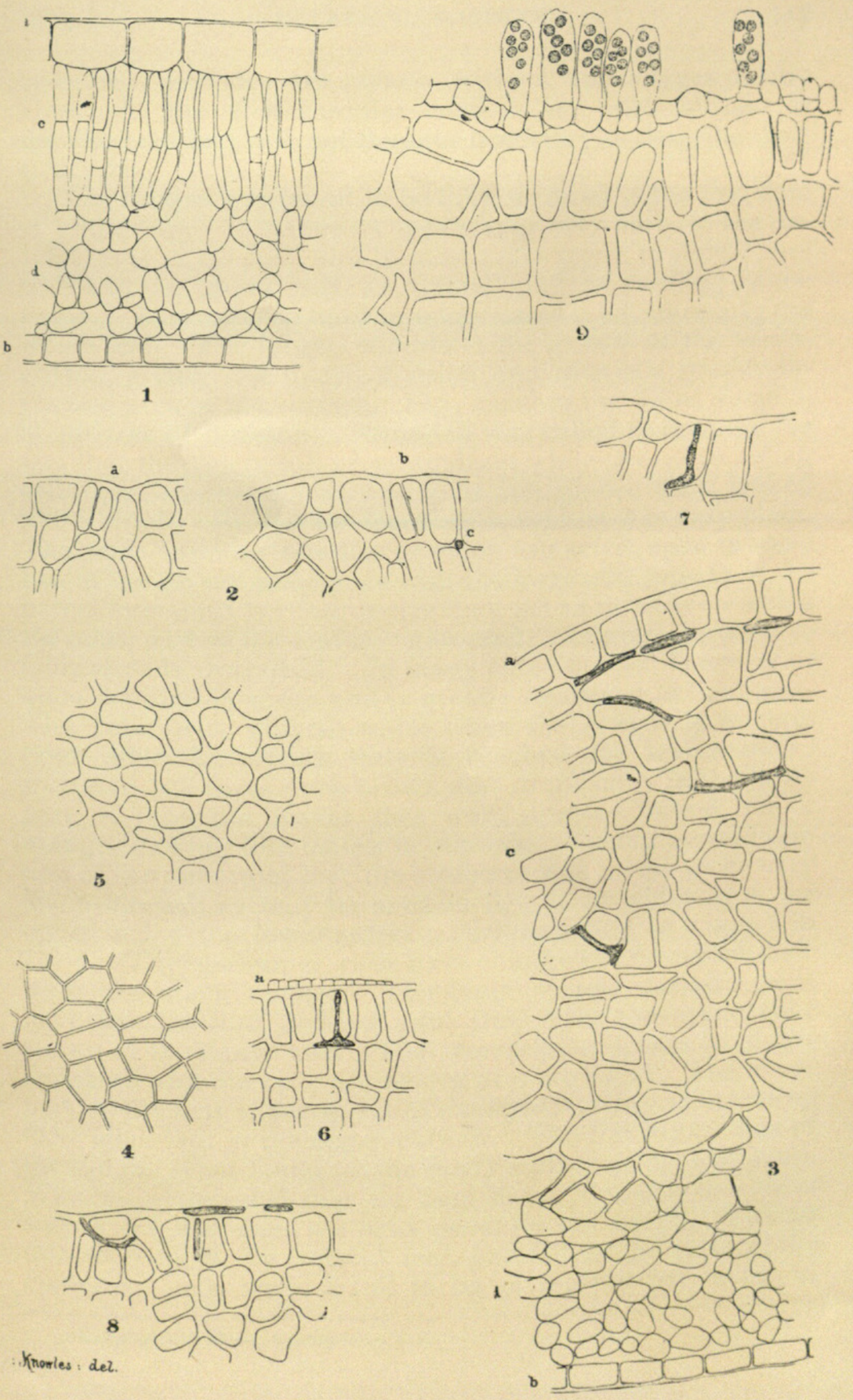
epidermal surfaces are smooth, without appendages of any kind. As the fibro-vascular bundles are little affected in the diseased leaf it is not thought necessary to describe their structure.

The fungus was found to be fully matured at the first date of gathering. It makes its appearance very early in the development of the leaf, and in most cases seems to start somewhere in the upper half, as a small puff or swelling in the tissue. This spreads until in many cases it affects nearly the whole leaf. The fungus stimulates the growth of the parenchyma, giving rise to cell-division and thus to a greatly increased area of the surface. Fig. 2 shows two cells, $a$ and $b$, in process of division. Attention was called to them by the fact that they were full of protoplasm while the surrounding cells were empty or nearly so. At first glance each looked like a single cell, but on focusing a septum was very plain. The fibro-vascular bundles or veins are acted upon to some extent but do not keep pace with the increased growth of the parenchymatous portion, hence they act as threads on which the other part of the leaf is " gathered," forming the puffs or folds already described. In many cases the leaf is nearly or quite doubled in width and is greatly increased in thickness. The color is a grayish-white when the fungus is mature. Soon after the mature state is reached the leaf becomes shriveled up, turns dark brown and drops off. In the latter part of June the leaves that were infected turned red or orange, looking like leaves in autumn. Taking a cross section of the abnormal leaf the structure was found to be very much altered, as may be seen in fig. 3 , in which $a$ is the upper and $b$ the lower surface, corresponding to $a$ and $b$ in fig. I. The epidermal cells have changed in form and their walls are much thicker. The long, narrow palisade cells have swollen and divided until they have the appearance shown in the figure at $c$. The intercellular spaces have disappeared and the cells are nearly or quite empty. The lower part of the leaf is not so much changed, the mycelium being most abundant in the upper portion. The fruiting portion of the fungus is not found on the lower surface of the leaf at all. Winter's statement ${ }^{2}$ that the asci break through the lower side of the leaf does not hold good for the peach. Taking thin sections of the normal leaf, parallel to the surface, the epidermal cells were found to be as represented in fig. 4 ,

${ }^{2}$ Kryptogamen-Flora, Ascomycetes, p. 6. 


\section{$2 \mathrm{BHL}$ Biodiversity Heritage Library}

Knowles, Etta L . 1887. "The "Curl" of Peach Leaves: A Study of the Abnormal Structure Induced by Exoascus deformans." Botanical gazette 12(9), 216-218. https://doi.org/10.1086/326167.

View This Item Online: https://www.biodiversitylibrary.org/item/90524

DOI: https://doi.org/10.1086/326167

Permalink: https://www.biodiversitylibrary.org/partpdf/221702

\section{Holding Institution}

Missouri Botanical Garden, Peter H. Raven Library

\section{Sponsored by}

Missouri Botanical Garden

\section{Copyright \& Reuse}

Copyright Status: Public domain. The BHL considers that this work is no longer under copyright protection.

This document was created from content at the Biodiversity Heritage Library, the world's largest open access digital library for biodiversity literature and archives. Visit BHL at https://www.biodiversitylibrary.org. 